Copyright (C) 2021 by Cherkas Global University

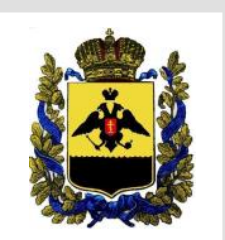

Published in the USA

Bylye Gody

Has been issued since 2006.

E-ISSN: $2310-0028$

2021. 16(4): 1671-1682

DOI: $10.13187 / \mathrm{bg} .2021 .4 .1671$

Journal homepage:

https://bg.cherkasgu.press

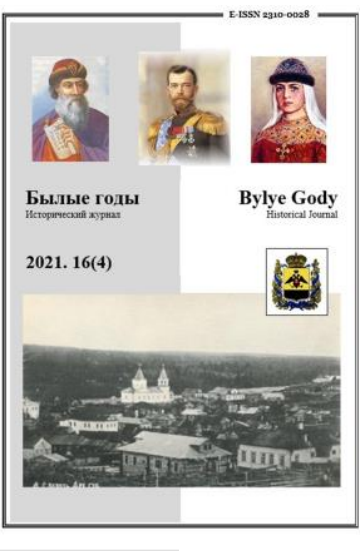

\title{
Cherkasovs (Keretskys): Historical and Genealogical Research (based on the Materials from the second half of the XVIII - first half of the XX centuries)
}

\author{
Aleksandr A. Cherkasov a, b , c, \\ a Cherkas Global University, Washington, USA \\ b Volgograd State University, Volgograd, Russian Federation \\ ${ }^{c}$ American Historical Association, Washington, USA
}

\begin{abstract}
The work examines the history of the Cherkasov family from Keret. The attention is paid to the founder of the surname, nine generations, as well as ancestral ties and other genealogical materials.

The author used the following documents as materials: the Russian State Archive of Ancient Acts (Moscow, Russian Federation), in which the documents of the 3rd revision of 1763 for the village of Keret were postponed; the State Archive of the Arkhangelsk region (Arkhangelsk, Russian Federation), in which the materials from the 4th to the 10th revision (1782-1858) were postponed; the National Archive of the Republic of Karelia (Petrozavodsk, Russian Federation), in which the metric books for the village of Keret were postponed; The Central Archive of the Ministry of Defense of the Russian Federation (Podolsk, Russian Federation), thanks to which the fate of several representatives of the genus who took part in World War II was established.

In conclusion, the author states that the ancestor of the Cherkasovs was a certain Prokofy (Prokopy), born around 1685. Prokofy, in all probability, belonged to the Cherkasy - Cossack ethnic group on the territory of modern Ukraine. Prokofy's son Cherkas Isak, who arrived in Keret in the late 1720s, was recorded as Isak Cherkasov and assigned to the peasant class. From the late 1720 s to the mid-1950s (until the closure of the village of Keret during the Soviet era) Cherkasov and the village of Keret will be inextricably linked. During this time, 7 generations of Cherkasovs were born in Keret (it should be recalled that the first two generations were newcomers - Prokofy and his son Isak). The Cherkasovs' main occupation in Keret was fishing. During the years of their life in the village Cherkasov performed state duties (recruited into the Russian army as recruits, took part in the First and Second World Wars), paid taxes. Among the Cherkasovs were industrialists before the revolution, engineers, officials, teachers, inventors, entrepreneurs in the Soviet and modern Russian periods. Among them were victims of political repression in the USSR and Soviet laureates of the state prize...
\end{abstract}

Keywords: Cherkasovs (Keretskys), Cherkas Prokofy, Isac Cherkasov, revisions, Keret village, Russian Empire.

\section{1. Введение}

Черкасовы - достаточно распространенная фамилия на постсоветском пространстве. К примеру, только по данным сайта «Подвиг народа», в Великой Отечественной войне приняли участие и были награждены не менее 5 тыс. мужчин - носителей этой фамилии. Именно поэтому мы решили добавить к фамилии и место проживания, а именно село Кереть (современной республики Карелия), так получилось название Черкасовы (Керетские).

\footnotetext{
${ }^{*}$ Corresponding author

E-mail addresses: a.cherkasov@cherkasgu.net (A.A. Cherkasov) 
Важно отметить, что Кереть являлась одним из старейших населенных пунктов русского севера, которое отсчитывало свою историю с периода конца XV - начала XVI вв. (Черкасов, 2013а: 15). Село находилось на берегу Белого моря, поэтому местные жители назывались поморами и занимались преимущественно рыбным промыслом. С момента основания села история населенного пункта была связана с историей рода Черкасовых. Сегодня родовое древо рода Черкасовых из Керети насчитывает около 250 имен, из них 81 человек приходился на первые 9 поколений с 1685 по 1954 гг. Важно пояснить, что последняя 9-я генерация началась в 1910 г. и закончилась в 1954 г., то есть началась последняя из изучаемых нами генераций еще в дореволюционный период.

\section{2. Материалы и методы}

В качестве материалов нами были использованы документы Российского государственного архива древних актов (Москва, Российская Федерация), в котором отложились документы 3-й ревизии 1763 г. по селу Кереть; государственного архива Архангельской области (Архангельск, Российская Федерация), в котором имеются материалы с 4-й по 10-ю ревизии (1782-1858 гг.); Национального архива республики Карелия (Петрозаводск, Российская Федерация), в котором хранятся метрические книги по селу Кереть; Центрального архива Министерства обороны Российской Федерации (Подольск, Российская Федерация), благодаря которым установлена судьба нескольких представителей рода, принявших участие во Второй мировой войне.

Важно сразу пояснить, что материалы в метрических книгах по Керетскому приходу Николаевской церкви представлены довольно эпизодично (церковь относилась к Архангельской духовной консистории по Керетской церкви, 3-го Кемского благочиния). Так, самые ранние метрические книги по Керетскому приходу имеются за 1861-1865 гг., потом до 1874 г. книг нет. В то же время с 1900 по 1919 г. записи представлены в полном объеме.

В методологическом плане в работе широко применен генеалогический метод исследования, благодаря которому удалось проследить девять поколений рода Черкасовых из Керети, выявить их родовые связи, а также высчитать генетическую силу рода. Инструментом для генеалогического анализа, таким образом, стал сбор информации о разных поколениях (генерациях) рода. Помимо этого, нами был использован ретроспективный метод, благодаря которому удалось рассмотреть события в их хронологической последовательности.

\section{3. Обсуждение и результаты}

Ввиду специфичности данной темы историография представлена только нашими работами, изданными в 2013 и 2021 гг. Среди работ 2013 г. можно указать труды по истории рода Черкасовых (Черкасов, 2013) и по истории села Кереть (Черкасов, 2013а). В 2021 г. были опубликованы статьи о двух представителях рода Черкасовых: выдающемся советском и российском изобретателе Павле Ивановиче Черкасове (Cherkasov, 2021a), участнике Первой мировой войны и жертве политических репрессий Феофане Ивановиче Черкасове (Cherkasov, 2021). В настоящее время ведутся работы по подготовке биографических исследований и о других представителях рода. Однако обо всем по порядку...

Самым ранним документом о происхождении рода Черкасовых в селе Кереть стали материалы 3-й ревизии, которая проводилась в Российской империи в 1763 г. Первичные материалы ревизии назывались ревизскими сказками. Согласно сказкам о государственных и монастырских крестьянах (русских и лопарях) Кольского уезда, вотчины Соловецкого монастыря, Керецкого села были зафиксированы следующие представители рода (выписку из этого документа мы решили представить полностью):

Таблица 1. Черкасовы в материалах 3-й ревизии 1763 г. (РГАДА. Ф. 350. Оп. 2. Кн. 1479. Л. 870б.-88)

\begin{tabular}{|c|c|c|c|c|}
\hline & & $\begin{array}{lr}\text { По последней } \\
\text { ревизии } & \text { в } \\
\text { подушный } & \text { оклад } \\
\text { написаны } & \end{array}$ & $\begin{array}{l}\text { Из оных после } \\
\text { ревизии } \\
\text { разными } \\
\text { случаями выбыли }\end{array}$ & \begin{tabular}{lr} 
Ныне & \multicolumn{2}{c}{ состоит } \\
налицо и & с \\
прибылыми & и \\
вновь & \\
рожденными & \\
\end{tabular} \\
\hline & & \multicolumn{3}{|c|}{ Лета } \\
\hline 981 & Исак Прокофьев сын Черкасов & 35 & & 52 \\
\hline & $\begin{array}{l}\text { У него жена Параскева, } 55 \text { лет } \\
\text { взята у бывшего Керецкого } \\
\text { села крестьянина Григория } \\
\text { Морозова }\end{array}$ & & & \\
\hline & $\begin{array}{l}\text { Н них дети, написанные в } \\
\text { бывшую ревизию }\end{array}$ & & & \\
\hline 982 & Андрей & 14 & & 31 \\
\hline
\end{tabular}




\begin{tabular}{|c|c|c|c|c|}
\hline 983 & Григорий & 5 & $\begin{array}{l}\text { Отдан в рекруты в } \\
1757 \text { г. }\end{array}$ & \\
\hline \multirow[t]{7}{*}{984} & Петр & $\begin{array}{l}\text { 1,2 (6 месяцев - } \\
\text { Авт.) }\end{array}$ & & $171 / 2$ \\
\hline & Рожденные после ревизии & & & \\
\hline & Мокей & & & 13 \\
\hline & Дочери & & & \\
\hline & $\begin{array}{lcr}\text { Марина, 25 } & \text { лет, отдана в } \\
\text { замужество } & \text { Двинского уезда } \\
\text { Кемского } & \text { городка } & \text { за } \\
\text { крестьянина Алексея Попова }\end{array}$ & & & \\
\hline & Катерина, 15 лет & & & \\
\hline & $\begin{array}{l}\text { У Андрея жена Домна, } 25 \text { лет } \\
\text { взята у керенчанина Ивана } \\
\text { Петрова }\end{array}$ & & & \\
\hline
\end{tabular}

Первая генерация (поколение). Согласно данным таблицы 1, мы можем видеть, что о родоначальнике Черкасовых из Керети известно сравнительно немного - звали его Прокофий. Достоверно известно, что сын у него родился в 1711 г., исходя из этого мы можем предположить, что Прокофий родился не позднее 1685 г. Так как жена его сына Исака была крестьянкой, то, вероятно, и род Черкасовых в Керети был крестьянским. Имя Прокофий в XVIII веке отождествляли с именем Прокопий, что в переводе с греческого языка означало Преуспевающий. С высокой степенью вероятности можно утверждать, что Прокофий не был местным, скорее всего, он был из черкас (казачьей этнической группы на территории правобережной Украины), с которыми у русского фронтира, коим являлся Соловецкий монастырь в то время, были весьма напряженные отношения. Стремясь облегчить эти отношения, русская администрация подготовила инструкцию для русских воевод, в которой рекомендовалось «черкасов добрых, семейных записывать на службу и наделять их пахотными землями, сеножатиями и всякими выгодами» (Дикий, 1960-1961). Для лучшей визуализации мы представили родоначальника Черкасовых из Керети на Рисунке 1.

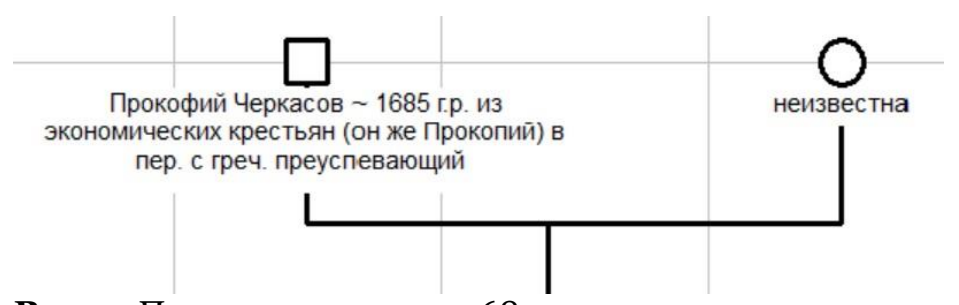

Рис. 1. Первая генерация $\sim 1685$ г.

Вторая генерация. В Керети из детей Прокофия был только один ребенок - его сын Исак. По всей вероятности, отпрыск казачьей вольницы Исак прибыл в Кереть в конце 1720-гг. как переселенец, где ему и дали фамилию Черкасов, так 18-летний черкас по имени Исак стал крестьянином Исаком Черкасовым. В это время в деревне была на выданье дочка местного крестьянина Григория Морозова - Параскева (она же Парасковья). Примерно в 1730 г. Исак и Параскева обвенчались, ему в то время было 19 лет, а Параскеве - 22. О том, что Исак жил в Керети с конца 1720-х гг., свидетельствует его женитьба на местной крестьянке. Также на это указывает учет его предыдущей ревизией (2-й) 1744 г. Кстати, 4-й ревизией в 1782 г. отчество Исака уже было записано как Прокопьевич.

Возраст: Исак скончался в 1776 г. в 65-летнем возрасте, его жена пережила его всего на 5 лет и умерла в 1781 году в возрасте 73 лет (ГААО. Ф. 51. Оп. 11. Т. 2. Д. 2674. Л. 189-189об.). Очень странно, но ни в 1-й ревизии 1719-1720 гг., ни во 2-й ревизии 1744-1745 гг. Черкасовы в селе Кереть не были обнаружены. Скорее всего, учет был неполным или же документы сохранились не полностью.

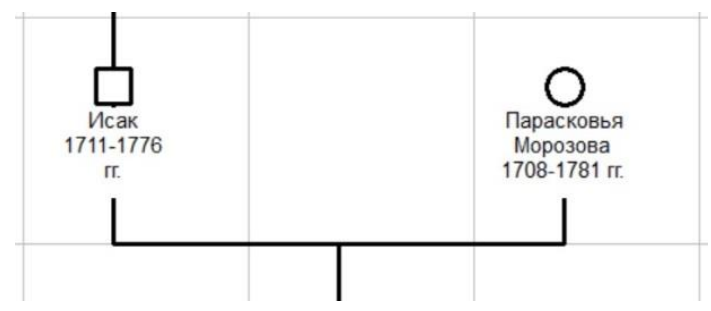

Рис. 2. Вторая генерация (1711 г.) 
Третья генерация (6 человек) (1731-1749 гг.). У Исака и Параскевы было 6 детей (4 сына и 2 дочери): первым ребенком был Андрей, родившийся в 1731 г., потом Марина 1737 г.р., Григорий 1741 г.р., Петр 1746 г.р., Катерина 1747 г.р. и последним был Мокей (он же Моисей) 1749 г.p. Мы можем видеть, что между первыми детьми был значительный временной интервал по 5-6 лет, а уже с 4-го ребенка между детьми был интервал 1-2 года. Последнего ребенка Параскева родила уже в возрасте 41 года. Судьба этого потомства складывалась достаточно успешно: так, все дети смогли пережить младенчество, то есть среди них лиц, умерших в детском возрасте, не было. Трое из четверых сыновей (Андрей, Петр и Мокей) впоследствии женились и имели потомство. Что касается Григория, то в 16-летнем возрасте в 1757 г. он был отдан в рекруты и в Кереть больше не возвращался, как сложилась его судьба, неизвестно. Катерина же, согласно материалам 4-й ревизии, к своим 34-м годам продолжала оставаться в девках (ГААО. Ф. 51. Оп. 11. Т. 2. Д. 2674. Л. 189-189об.).

Браки: Старший сын Исака Андрей женился на дочери керетского крестьянина Ивана Петрова - Домне (она же Домника) 1734 г.р. (жених был старше на 3 года). Петр в свою очередь женился на дочери керетского крестьянина по имени Евдокия 1745 г.р. (невеста была старше на 1 год), Мокей также женился на дочери керетского крестьянина по имени Акилина 1749 г. (жених и невеста были ровесниками). Старшая дочь Марина в 18-летнем возрасте в 1780 г. вышла замуж за крестьянина Алексея Попова (Двинской уезд Кемский городок) (РГАДА. Ф. 35О. Оп. 2. Кн. 1479. Л. 870б.-88).

Возраст: Андрей достиг преклонных лет, скончался в возрасте 73 года в 1804 г. (ГААО. Ф. 51. Оп. 11. Т. 2. Д. 3261. Л. 550б.) Петр погибнет в результате несчастного случая в море в 1791 г. вместе с двумя старшими сыновьями (ГААО. Ф. 51. Оп. 1. Т. 2. Д. 2711. Л. 116-116об.). Мокей умрет в 1807 г. в возрасте 58 лет (ГААО. Ф. 51. Оп. 11. Т. 2. Д. 3261. Л. 55об.).

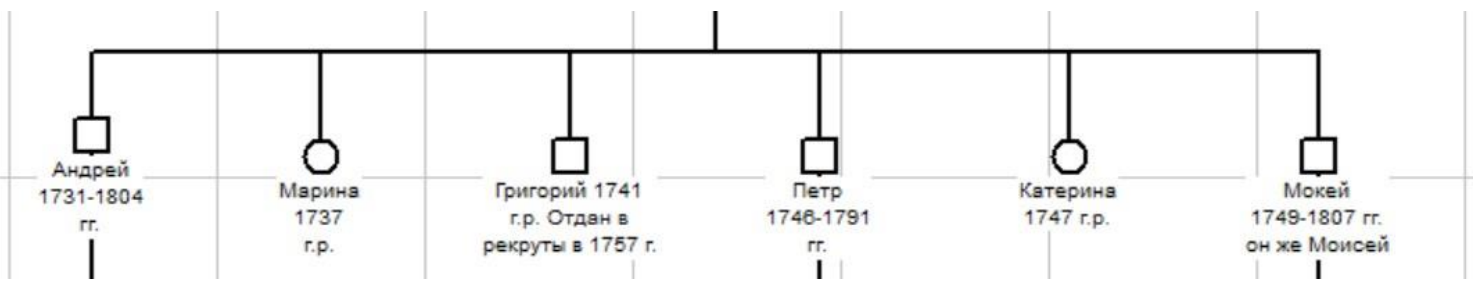

Рис. 3. Третья генерация (1731-1749 гг.)

Четвертая генерация (13 человек) (1764-1789 гг.). Уже в четвертом поколении по мужской линии Черкасовых возникают три ветви. Первая ветвь - дети Андрея и Домны (один сын и три дочери): Антон 1764 г.р., Наталья 1769 г.р., Фекла 1770 г.р. и Ксения (она же Оксенья) 1775 г.р. Вторая ветвь - дети Петра и Евдокии (четыре сына и одна дочь): Антон 1776 г.р., Семен 1777 г.p. Демид (он же Дмитрий) 1779 г.р., Емельян 1786 г.р. и Неонила 1789 г.р. Третья ветвь - дети Мокея и Акилины (один сын и три дочери): Корнил (он же Корнило) 1772 г.р., Марфа - примерно 1775 г.p., Евдокия 1777 г.р. и Неонила 1780 г.р. (ГААО. Ф. 29. Оп. 29. Д. 22. Л. 61об.-62).

Судьба Черкасовых четвертого поколения будет складываться по-разному. Из детей Андрея единственный его сын (Антон) женится на дочери керетского крестьянина Ирине 1767 г.p. (жених старше на 3 года), а его старшая дочь Наталья умрет в 10-летнем возрасте, о судьбе двух других дочерей сведений не обнаружено. Что касается детей Петра, то двое старших сыновей (Антон и Семен) погибнут вместе с отцом на промысле в 1791 г. (Антону было в то время 15 лет, а Семену - 14) (ГААО. Ф. 51. Оп. 11. Т. 2. Д. 2711. Л. 116-116об.). Емельян погибнет 10-летнем возрасте в 1796 г. Последний сын Петра Демид в самом начале $1800-\mathrm{x}$ гг. женился на дочери керетского крестьянина Параскеве 1785 г.р. (жених старше на 6 лет) (ГААО. Ф. 51. Оп. 11. Т. 4. Д. 8437. Л. 3290б.-330). Сын Мокея Корнило женился в Керети на крестьянской дочери Анне 1777 г.р., его старшая дочь умрет в младенчестве в возрасте около 5 лет. Судьба других дочерей (Евдокии и Неонилы) также неизвестна.

Возраст: Антон умрет в возрасте 54 лет в 1818 г., Демид умрет в 1823 г. в возрасте 44 лет (ГААО. Ф. 51. Оп. 11. Т. 8. Д. 12870. Л. 146об.-147). Корнило переживет своих двоюродных братьев и умрет в возрасте 65 лет в 1837 г. (ГААО. Ф. 51. Оп. 11. Т. 23. Д. 310. Л. 750б.-76).

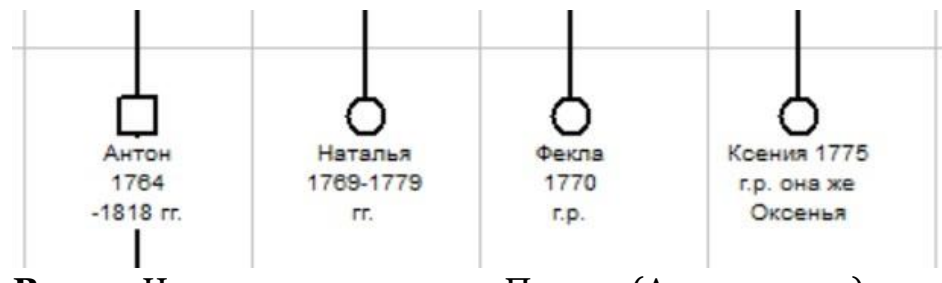

Рис. 4. Четвертая генерация. Первая (Андреевская) ветвь 


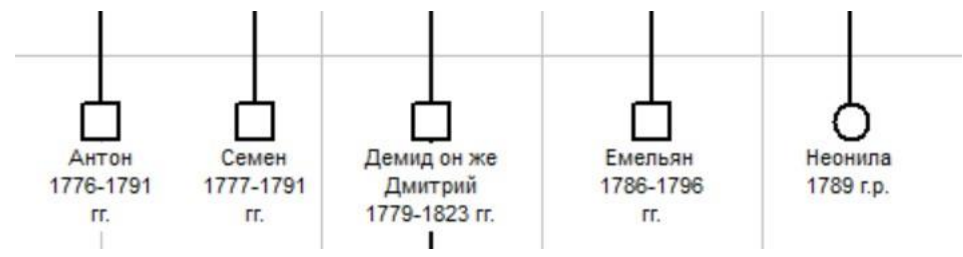

Рис. 5. Четвертая генерация. Вторая (Петровская) ветвь

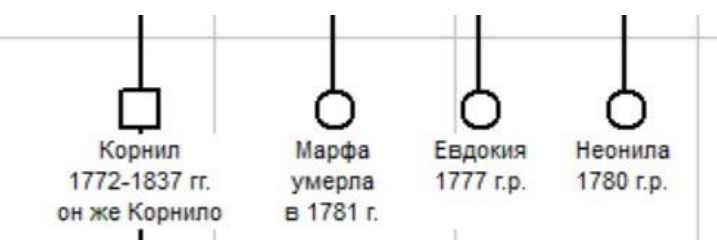

Рис. 6. Четвертая генерация. Третья (Мокеевская) ветвь

Пятая генерация (8 человек) (1793-1818 гг.). Пятая генерация также была представлена тремя ветвями. Первая ветвь - дети Антона и Ирины: Параскева 1793 г.р., Иван 1796 г.р., Елена 1800 г.р.; вторая ветвь - дети Демида и Параскевы: Устина 1805 г.р., Настасья 1809 г.р., Екатерина 1814 г.р. и Илья 1818 г.р.; третья ветвь - дети Корнило и Анны: одна дочь Настасья 1801 г.р.

Браки: Иван Антонович женится на Матрене 1802 г.р., Илья Демидович женится на Марине 1813 г.p. (ГААО. Ф. 51. Оп. 11. Т. 8. Д. 12870. Л. 146об.-147). Помимо этого, оставит потомство, ставшее Черкасовыми, Настасья Демидовна, родившая четырех детей вне брака.

Возраст: Мужчины 5-й генерации умрут в возрасте до 40 лет. Так, Иван Антонович умрет в 1833 г. в возрасте 37 лет (ГААО. Ф. 51. ОП. 11. Т. 8. Д. 12870. Л. 146об.-147), а Илья Демидович умрет в 1857 г. в возрасте 39 лет (ГААО. Ф. 51. Оп. 11. Т. 23. Д. 421. Л. 200б.-22). Что касается Настасьи Демидовны, то она умрет в 1884 г. в почтенном возрасте - 75 лет (Черкасов, 2013: 48).

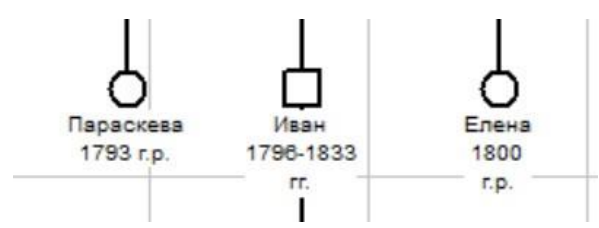

Рис. 7. Пятая генерация. Первая (Антоновская) ветвь
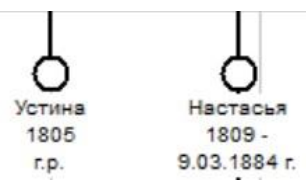

I

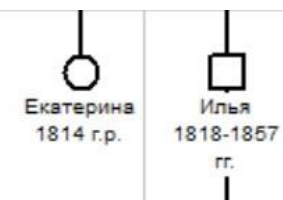

Рис. 8. Пятая генерация. Вторая (Демидовская) ветвь

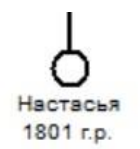

Рис. 9. Пятая генерация. Третья (Корниловская) ветвь

Шестая генерация (10 человек) (1822-1850 гг.). Шестая генерация также представлена тремя ветвями. Первая ветвь - дети Ивана и Матрены (два сына и дочь): Филипп 1822 г.р., Степан (он же Стефан) 1825 г.р. и Мария 1830 г.р.; вторая ветвь - дети Ильи и Марины (три дочери): Степанида 1844 г.р., Просковья 1847 г.р. и Васса 1848 г.р.; третья ветвь - дети Настасьи, рожденные вне брака (три сына и дочь): Демьян 1836 г.р., Марк 1839 г.р., Евдокия 1845 г.р. и Агапит (он же Агафон) 1850 г.р. (ГААО. Ф. 51. Оп. 11. Т. 23. Д. 421. Л. 200б.-22)

Браки: Филипп Иванович женился на Устине Даниловне 1826 г.р. (жених был старше на 4 года). Агапит женился на Параскеве Семеновне 1853 г.p. (жених был старше на 3 года) (ГААО. Ф. 51. Оп. 11. Т. 23. Д. 421. Л. 200б.-22). 


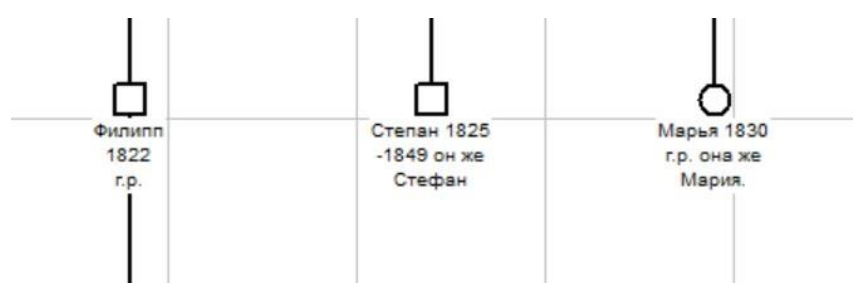

Рис. 9. Шестая генерация. Первая (Ивановская) ветвь

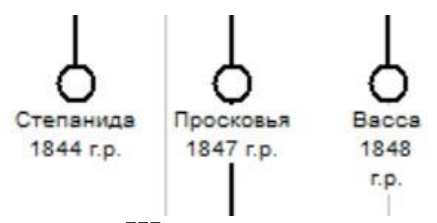

Рис. 10. Шестая генерация. Вторая (Ильинская) ветвь

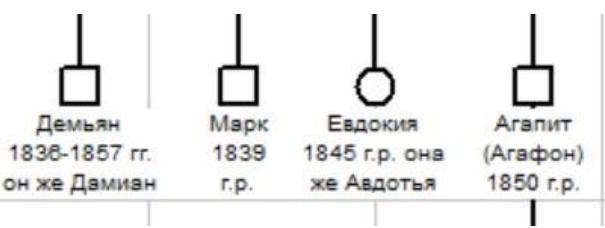

Рис. 11. Шестая генерация. Третья ветвь (внебрачное потомство Настасьи)

Ввиду отсутствия мужчин вторая (Ильинская) ветвь затухла. Однако первая (Ивановская) и третья (потомство Настасьи) дали потомство.

Седьмая генерация (14 человек) (1848-1897 гг.). Седьмая генерация представлена двумя ветвями. Первая ветвь - дети Филиппа и Устины Даниловны (4 дочери и три сына): Параскева 1848 г.р., Епистимия 1851 г.р., Катерина 1853 г.р. Иван 1856 г.р., Иван 1859 г.р., Яков 1861 г.р. и Александра 1864 г.р.; вторая ветвь - дети Агапита и Параскевы Семеновны (5 сыновей и 2 дочки): Леонтий 1875 г.p., Алексей 1877 г.p., Евдокия 1881 г.p., Михаил 1884 г.p., Анна 1886 г.p., Петр 1888 г.p. и Семен 1897 г.р. (ГААО. Ф. 29. ОП. 29. Д. 400. Л. 553-553об.). Из трех сыновей Филиппа двое не дожили и до 5 лет (Иван, родившийся в 1859 г., и Яков), а из пяти сыновей Агапита в возрасте до 11 лет умерли трое (старшие сыновья Леонтий, Алексей, Михаил). Важно пояснить, что в 1880-е гг. в Керети свирепствовала скарлатина, которая и стала причиной высокой смертности среди детей в Керети (Черкасов, 2013: 49).

Браки: Иван Филиппович женился на Гликерии Сергеевне (в девичестве Дворникова) 1857 г.p. (невеста была старше на 1 год) (ГААО. Ф. 29. Оп. 29. Д. 510. Л. 9120б.-913). Семен Агапитович женился на Таисии Андреевне (в девичестве Оборина) 1896 г.р. (невеста была старше на 1 год) (ГААО. Ф. 29. Оп. 29. Д. 478. Л. 5830б.-584).

Возраст: Иван Филиппович скончался 20 января 1900 г., в возрасте 44 лет (Черкасов, 2013: 49), его жена Гликерия умерла 9 марта 1918 г. на 63-м году жизни (Черкасов, 2013: 52). Что касается Семена Агапитовича, то в годы Второй мировой войны он был призван в армию и пропал без вести в октябре 1941 г. (ЦАМО РФ. Ф. 58. ОП. 977520. Д. 960. Л. 81).

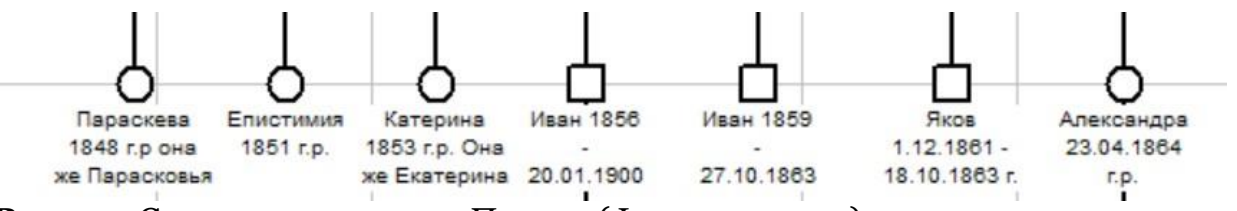

Рис. 12. Седьмая генерация. Первая (Филипповская) ветвь

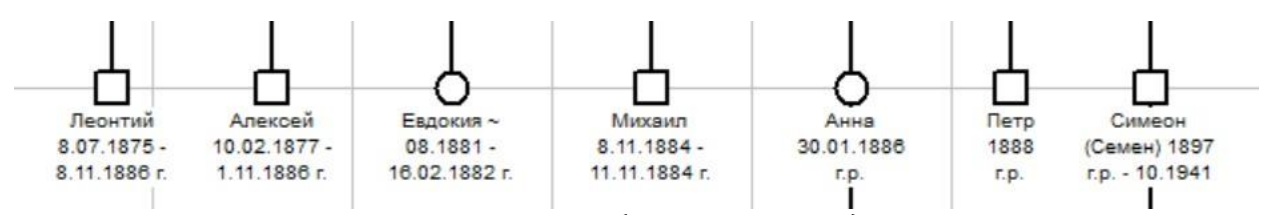

Рис. 13. Седьмая генерация. Вторая (Агапитовская) ветвь

Восьмая генерация (14 человек) (1879-1925 гг.). Восьмая генерация представлена также двумя ветвями. Первая - дети Ивана и Гликерии (10 человек -8 сыновей и 2 дочки, последний из сыновей родился вне брака уже после смерти отца семейства): Александр 1879 г.p., Анна 1881 г.p., Павел 1882 г.р., Филипп 1885 г.р., Феофан 1886 г.р., Степан 1889 г.р., Павла 1893 г.р., Алексей в 
начале 1890-х гг., Петр 1896 г.р. и последний Иван 1902 г.р.; вторая ветвь - дети Семена и Таисии (три дочери и сын): Апфия 1916 г.р., Августа 1918 г.р., Федор 1922 г.р. и дочь (имя начинается на букву А., полное имя установить не удалось) 1925 г.р.

Браки: Павел Иванович женился на Марии Андреевне 1888 г.р. (жених был на 6 лет старше), Феофан Иванович женился на Наталии Ефимовне (в девичестве Савина) 1893 г.р. (жених был на 7 лет старше) (Черкасов, 2013: 50), последний сын Иван Иванович женился в первый раз на Анастасии Ивановне 1904 г.р. (жених был старше на 2 года), а позднее - на Анастасии Андреевне (в девичестве Кемова) 1909 г.р. (жених был старше на 7 лет). Семен Агафонович женился на керетской крестьянке Таисии Андреевне Обориной 1896 г.р. (невеста была на 1 год старше) (Черкасов, 2013: 51).

Возраст: много детей восьмой генерации умерли в младенчестве от родимца. Анна Ивановна прожила всего 3 месяца, Филипп - только 6 дней, Алексею не было и 6 лет, не достиг 18 лет старший сын Александр Иванович. Феофан был расстрелян в период политических репрессий в 1938 г. (Cherkasov, 2021: 79). В семье Семена Агапитовича Апфия умерла в возрасте 3 месяцев, а Федор погиб в концентрационном лагере в 1942 г. (ЦАМО. Ф. 58. Оп. 977520. Д. 960. Л. 81). Иван Иванович прожил 67 лет и скончался в 1969 г., сказались 5 ранений, полученных в годы Второй мировой войны (Черкасов, 2013: 57).

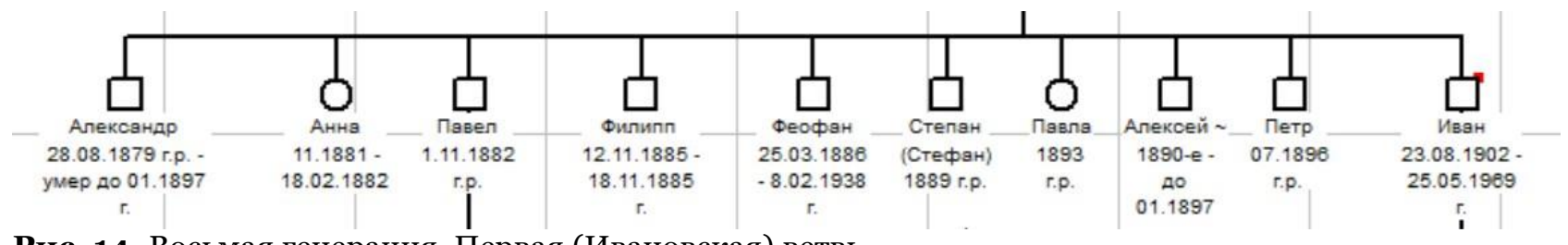

Рис. 14. Восьмая генерация. Первая (Ивановская) ветвь

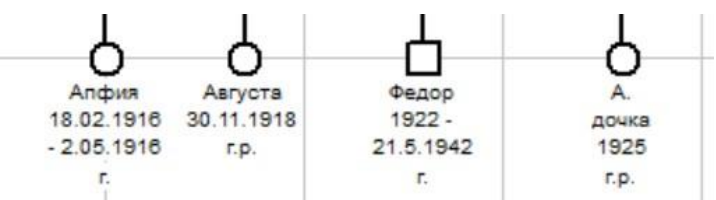

Рис. 15. Восьмая генерация. Вторая (Семеновская) ветвь

После гибели на войне Федора вторая (Семеновская) ветвь по мужской линии затухла, но первая (Ивановская) ветвь дала большое потомство.

Девятая генерация (14 человек) (1910-1954 гг.). Представлена генерация тремя ветвями. Первая ветвь - дети Павла Ивановича и Марии Андреевны (5 дочерей и 2 сына): Алексей 1910 г.р., Петр 1913 г.р. (ГААО. Ф. 29. Оп. 29. Д. 684. Л. 539), Анна 1916 г.р., Клавдия 1919 г.р., Евгения 1921 г.р., Маргарита 1926 г.р. и Александра примерно 1930 г.р.; вторая ветвь - дети Феофана Ивановича и Наталии Ефимовны: дочь Анна 1912 г.р. (Черкасов, 2013: 50); третья ветвь - дети Ивана Ивановича и Анастасии Ивановны (первый брак): дочь Валентина 1931 г.р. и сын Леонид 1934 г.р., а также от второго брака с Анастасией Андреевной (два сына и две дочери): Федор 1936 г.р., Павел 1938 г.р., Клавдия 1949 г.р. и Людмила 1954 г.p. (Cherkasov, 2021a: 24).

Браки по мужской линии: Алексей Павлович женился на Ульяне Федоровне (в девичестве Прокопьева) 1916 г.р. (жених был старше на 6 лет), Петр Павлович также был женат, но имя жены установить не удалось, Леонид Иванович был женат первым браком на Наталье, а вторым браком на Зое 1935 г.p. (жених был на 1 год старше), Павел Иванович был женат на Марии 1940 г.р. (жених был старше на 2 года).

Возраст: Алексей Павлович умер в возрасте 59 лет в 1969 г., сказались ранения в годы Второй мировой войны, Петр Павлович погиб в годы Второй мировой войны в 1942 г. в возрасте 29 лет, Павел Иванович скончался в 2010 г., прожив 72 года (Cherkasov, 2021a: 34).

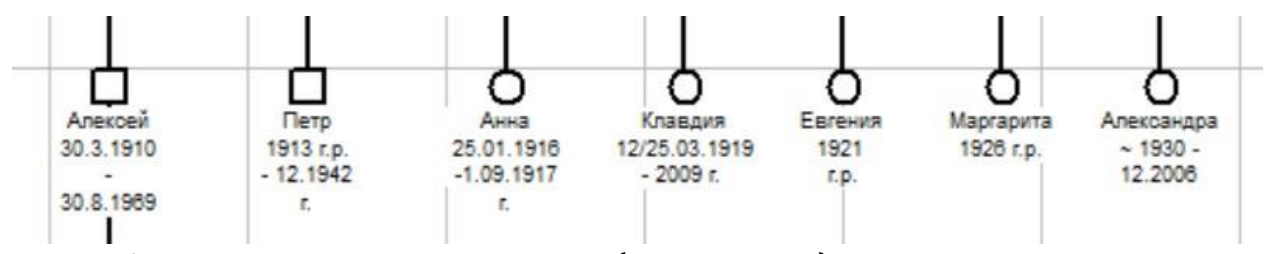

Рис. 16. Девятая генерация. Первая (Павловская) ветвь 


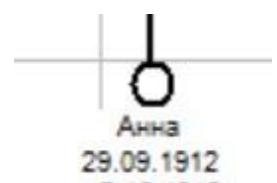

$-7.12 .1912$

Рис. 17. Девятая генерация. Вторая (Феофановская) ветвь

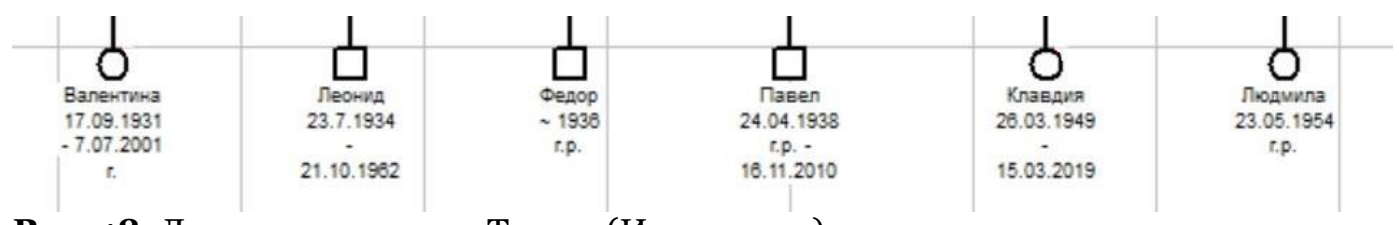

Рис. 18. Девятая генерация. Третья (Ивановская) ветвь

Вторая (Феофановская) ветвь затухла, но первая (Павловская) и третья (Ивановская) ветви дали в последующем большое потомство.

Таблица 2. Генерации (поколения) рода Черкасовых из Керети (1685-1954 гг.)

\begin{tabular}{|l|l|l|l|}
\hline $\begin{array}{l}\text { Генерация } \\
\text { (поколения) }\end{array}$ & Годы & Ветви & $\begin{array}{l}\text { Количество } \\
\text { людей }\end{array}$ \\
\hline Первое & 1685 & одна & 1 \\
\hline Второе & 1711 & одна & 1 \\
\hline Третье & $1731-1749$ гг. & одна & 6 \\
\hline Четвертое & $1764-1789$ гг. & три & 13 \\
\hline Пятое & $1793-1818 г г$. & три & 8 \\
\hline Шестое & $1822-1850$ гг. & три & 10 \\
\hline Седьмое & $1848-1897$ гг. & две & 14 \\
\hline Восьмое & $1879-1925 г г$. & две & 14 \\
\hline Девятое & $1910-1954$ гг. & три & 14 \\
\hline
\end{tabular}

Важным источником генеалогического характера являются материалы Первой всеобщей переписи населения Российской империи 1897 года (28 января) по селу Кереть Керетского сельского общества и волости Кемского уезда Архангельской губернии. По данным на 1897 г., в Керети проживали две семьи Черкасовых:

1. Семья Агафона (незаконнорожденный) Черкасова, проживавшая в собственном дворе (построено и крыто деревом).

Состав семьи:

- Черкасов Агафон (н.з.) - хозяин, 45 лет, женат; крестьянин из государственных; родился, приписан, обыкновенно проживает - здесь; православный; родной язык - русский; неграмотный; главное занятие, которое доставляет средства для существования, - рыбопромышленник, хозяин.

- Черкасова Параскева Семеновна - жена, 46 лет; крестьянка из государственных; родилась, приписана, обыкновенно проживает - здесь; православная; родной язык - русский; неграмотная; главное занятие - при муже.

- Черкасова Анна Агафоновна - дочь, 10 лет; крестьянка из государственных; родилась, приписана, обыкновенно проживает - здесь; православная; родной язык - русский; грамотная, обучалась в церковноприходской школе; главное занятие - при родителях (ГААО. Ф. 6. Оп. 9. Д. 28. Л. 100-101).

2. Семья Ивана Филипповича Черкасова, прожившая в собственном дворе (во дворе жилых строений -1 , построено и крыто деревом).

Состав семьи:

- Черкасов Иван Филиппович - хозяин, 41 год, женат; крестьянин из государственных; родился, приписан, обыкновенно проживает - здесь; православный; родной язык - русский; грамотный, обучался в 1-классном училище Министерства народного просвещения; главное занятие, которое доставляет средства для существования, - рыбопромышленник, хозяин; побочное занятие - рабочий поденщик.

- Черкасова Гликерия Сергеевна - жена, 40 лет; крестьянка из государственных; родилась Архангельская губерния, Кемский уезд; приписана, обыкновенно проживает - здесь; православная; родной язык - русский; неграмотная; главное занятие - при муже.

- Черкасов Павел Иванович - сын, 14 лет; крестьянин из государственных; приписан, обыкновенно проживает - здесь; православный; родной язык - русский; грамотный, обучался в церковноприходской школе; главное занятие - при родителях. 
- Черкасов Феофан Иванович - сын, 10 лет; крестьянин из государственных; приписан, обыкновенно проживает - здесь; православный; родной язык - русский; неграмотный; главное занятие - при родителях.

- Черкасов Степан Иванович - сын, 8 лет; крестьянин из государственных; приписан, обыкновенно проживает - здесь; православный; родной язык - русский; неграмотный; главное занятие - при родителях.

- Черкасов Петр Иванович - сын, 6 месяцев; крестьянин из государственных; приписан, обыкновенно проживает - здесь; православный; родной язык - русский; главное занятие - при родителях.

- Черкасова Павла Ивановна - дочь, 4 года; крестьянка из государственных; приписана, обыкновенно проживает - здесь; православная; родной язык - русский; при родителях (ГААО. Ф. 6. Оп. 9. Д. 28. Л. 149-150).

Первая Всероссийская перепись 28 января 1897 г. оставила подробные сведения о грамотности в роду Черкасовых. Так, на момент переписи грамотным был Иван Филиппович Черкасов, которому к этому времени было уже 41 год (по всей вероятности, грамоте он обучен был еще ранее). Примечательным является то, что по переписи 1897 г. грамотными были лишь 13 \% населения Российской империи.

В немногочисленных материалах по рекрутской повинности встречается Григорий Исакович Черкасов 1741 г.р., который был отдан в рекруты в 16-летнем возрасте, то есть в 1757 г. В Первую мировую войну в армии служил Феофан Иванович Черкасов, по всей вероятности, в битве под Танненбергом в составе 2-й армии генерала Самсонова он попал в плен и до 1918 г. находился в австрийском лагере для военнопленных. Установить полк, в котором служил Феофан, не удалось.

Род Черкасовых был из экономических, то есть лично свободных крестьян. Род проживал достаточно дружно. В поддержку этого тезиса может служить то, что практически все Черкасовы принимали участие в бракосочетаниях в качестве поручителей, а также становились восприемниками (крестными) на крещениях детей. Так, например, 10 декабря 1861 г. на крестинах Якова сына Филиппа Иванова Черкасова крестной была крестьянская девка Степанида Ильина Черкасова. 24 января 1874 г. на бракосочетании крестьянской девицы Прасковьи Ильиничны Черкасовой и крестьянина Ивана Антонова Пайкачева поручителями со стороны невесты были Агапит Черкасов и Иван Филиппов Черкасов.

Что касается нз (незаконнорожденный), то их количество в с. Кереть было значительным около 10 \%. Нз были не только в семьях Черкасовых, но и Михниных, Лангуевых и даже дочь почетного гражданина купца Савина родила ребенка вне брака.

Помимо этого, имеется несколько семей Черкасовых в городе Кемь и Тунгудском приходе (Лаврентий и Василий, начало XX века), а также в Прионежском районе (Степан и Стаф, начало $\mathrm{XX}$ века). Однако говорить о родственных связях здесь преждевременно.

Подробно обследованы каботажные книги по судам, имеющим место приписки к селу Кереть. Среди судовладелецев Черкасовых нет. Рассмотрены также материалы мировых судов по участкам Кемского уезда, находящихся под следствием или судимых Черкасовых не обнаружено.

Средний возраст жизни в роду Черкасовых. Уделим некоторое внимание статистике в расчете генетической силы рода, а соответственно и продолжительности жизни в роду. Для этого сделаем выборку по лицам дат рождения и смерти, которые известны. Период, который охвачен статистическим исследованием, составляет 307 лет, то есть с 1711 по 2019 гг. В список мы включили Черкасовых обоих полов без их жен и мужей. Таким образом, мы выявили 39 человек (Таблица 3).

Таблица 3. Даты жизни представителей рода Черкасовых (1711-2019 гг.)

\begin{tabular}{|l|l|l|l|}
\hline $\begin{array}{l}\text { № } \\
\text { пП }\end{array}$ & Имя & Годы жизни & Количество прожитых лет \\
\hline 1 & Исак & $1711-1776$ гг. & 65 \\
\hline 2 & Андрей & $1731-1804$ гг. & 73 \\
\hline 3 & Петр & $1746-1791$ гг. & 45 \\
\hline 4 & Мокей & $1749-1807$ гг. & 58 \\
\hline 5 & Антон & $1764-1818$ гг. & 54 \\
\hline 6 & Наталья & $1769-1779$ гг. & 10 \\
\hline 7 & Антон & $1776-1791$ гг. & 15 \\
\hline 8 & Семен & $1777-1791$ гг. & 14 \\
\hline 9 & Демид & $1779-1823$ гг. & 44 \\
\hline 10 & Емельян & $1786-1796$ гг. & 13 \\
\hline 11 & Корнил & $1772-1837$ гг. & 65 \\
\hline 12 & Иван & $1796-1833$ гг. & 37 \\
\hline 13 & Анастасия & $1809-1884$ гг. & 75 \\
\hline
\end{tabular}




\begin{tabular}{|c|c|c|c|}
\hline 14 & Илья & 1818-1857 гг. & 39 \\
\hline 15 & Демьян & $1836-1857$ гг. & 21 \\
\hline 16 & Агафон & 1841-1919 гг. & 78 \\
\hline 17 & Иван & 1857-1900 гг. & 43 \\
\hline 18 & Иван & 1859-1863 гг. & 4 \\
\hline 19 & Яков & 1861-1863 гг. & 2 \\
\hline 20 & Леонтий & $1875-1886$ гг. & 11 \\
\hline 21 & Алексей & $1877-1886$ гг. & 9 \\
\hline 22 & Евдокия & 1881-1882 гг. & 2 \\
\hline 23 & Анна & 1881-1882 гг. & 2 \\
\hline 24 & Михаил & 1884-1884 гг. & 1 \\
\hline 25 & Филипп & $1885-1885$ гг. & 1 \\
\hline 26 & Феофан & 1886-1938 гг. & 52 \\
\hline 27 & Семен & 1897-1941 гг. & 44 \\
\hline 28 & Иван & 1902-1969 гг. & 67 \\
\hline 29 & Алексей & 1910-1969 гг. & 59 \\
\hline 30 & Петр & 1913-1942 гг. & 29 \\
\hline 31 & Анна & 1912-1912 гг. & 1 \\
\hline 32 & Апфия & 1916-1916 гг. & 1 \\
\hline 33 & Анна & 1916-1917 гг. & 2 \\
\hline 34 & Клавдия & 1919-2009 гг. & 90 \\
\hline 35 & Федор & 1922-1942 гг. & 20 \\
\hline 36 & Леонид & $1933-1963$ гг. & 30 \\
\hline 37 & Валентина & 1931-2001 гг. & 70 \\
\hline 38 & Павел & 1938-2010 гг. & 72 \\
\hline 39 & Клавдия & 1949-2019 гг. & 69 \\
\hline
\end{tabular}

Общий возраст перечисленных в списке лиц - 1387 лет, что в пересчете на одну душу составляет всего 35,5 лет. Основная доля дат жизни приходится на дореволюционный период. В результате вот она - мифическая цифра среднего возраста человека в царское время: дескать, много не жили! На самом же деле 8 человек в роду не достигли и 3 лет, причинами этого были как природная слабость, так и болезни, эпидемии. Если исключить детей и начать отсчет от совершеннолетних с 21 года до 59 лет, то в этой возрастной группе в роду имеется 10 человек умерших (из них точные данные есть по 4, так Леонид погиб, Феофан был расстрелян, Петр и Семен погибли на войне). Помимо этого, скоропостижную смерть Петра Черкасова и двух его сыновей в 1791 г. мы склонны связывать с гибелью в море. То есть из указанных 12 человек данной возрастной группы минимум 5 погибли от внешних факторов, а не от старости. Если исключить тех, кто умер в младенческом или детском возрасте, а также погибших в результате войн или несчастных случаев, то в нашем списке останется всего 17 человек (Таблица 4).

Таблица 4. Лица, умершие по естественным причинам

\begin{tabular}{|l|l|l|l|}
\hline № пп & Имя & Годы жизни & Количество прожитых лет \\
\hline 1 & Исак & $1711-1776$ гг. & 65 \\
\hline 2 & Андрей & $1731-1804$ гг. & 73 \\
\hline 3 & Мокей & $1749-1807$ гг. & 58 \\
\hline 4 & Антон & $1764-1818$ гг. & 54 \\
\hline 5 & Демид & $1779-1823$ гг. & 44 \\
\hline 6 & Корнил & $1772-1837$ гг. & 65 \\
\hline 7 & Иван & $1796-1833$ гг. & 37 \\
\hline 8 & Анастасия & $1809-1884$ гг. & 75 \\
\hline 9 & Илья & $1818-1857$ гг. & 39 \\
\hline 10 & Агафон & $1841-1919$ гг. & 78 \\
\hline 11 & Иван & $1856-1900$ гг. & 44 \\
\hline 12 & Иван & $1902-1969$ гг. & 67 \\
\hline 13 & Алексей & $1910-1969$ гг. & 59 \\
\hline 14 & Валентина & $1931-2001$ гг. & 70 \\
\hline 15 & Клавдия & $1919-2009$ гг. & 90 \\
\hline 16 & Павел & $1938-2010$ гг. & 72 \\
\hline 17 & Клавдия & $1949-2019$ гг. & 69 \\
\hline
\end{tabular}


Иными словами, из умерших по естественным причинам в 30-39 лет - 2 человека, 40-49 лет 2 человека, 50-59 лет значится 3 человека, в возрасте 6о-69 лет - 4 человека, 70-79 лет - 5 человек, 80-89 лет - нет и 90-99 лет - 1 человек.

Таким образом, средний возраст в роду Черкасовых (за последние 300 лет) составляет 62,2 года. Однако необходимо понимать, что в XVIII - первой половине XX вв. смертность была высока и по не зависящим от генетики причинам (например, голод и эпидемии). В результате, как нам представляется, сегодня максимальный возраст можно увеличить как минимум на 10 лет. Это, на наш взгляд, и является генетической силой рода. При этом для женщин средняя продолжительность жизни в период 1809-2019 гг. составляет 76 лет, а для мужчин в период 1711-2010 гг. - 52 года (резкое понижение связано со странными смертями четырех мужчин Черкасовых в XIX веке в возрастном диапазоне от 30 до 40 лет включительно, помимо этого, двое Черкасовых вернулись со Второй мировой войны получившими ранения, что также способствовало их преждевременному уходу). Данные цифры не являются окончательными, так как с введением в работу новых материалов они могут корректироваться, что, вне всякого сомнения, придаст точности статистическому учету.

\section{4. Заключение}

Завершая работу, мы хотели бы подвести следующие итоги:

1. Согласно документам Российского государственного архива древних актов, родоначальником Черкасовых был некто Прокофий (Прокопий), родившийся примерно в 1685 г. Прокофий, по всей вероятности, относился к черкасам - казачьей этнической группе на территории современной Украины. Сын Прокофия черкас Исак, прибывший в конце 1720-х гг. в Кереть, был записан как Исак Черкасов и определен в крестьянское сословие.

2. С конца 1720-х гг. и до середины 1950-х гг. (вплоть до закрытия села Кереть в годы советской власти) Черкасовы и село Кереть будут неразрывно связаны. За это время в Керети родилось 7 поколений Черкасовых (нужно напомнить, что первые два поколения были пришлыми - Прокофий и его сын Исак). Главным занятием Черкасовых в Керети был рыбный промысел. За годы своей жизни в селе Черкасовы исполняли государственные повинности (набирались в русскую армию в качестве рекрутов, принимали участие в Первой и Второй мировых войнах), платили налоги. Среди Черкасовых были промышленники до революции, инженеры, чиновники, учителя, изобретатели, предприниматели в советский и современный российский периоды. Среди них были жертвы политических репрессий в СССР и советские лауреаты государственной премии... Мы полагаем, что на совокупности судеб представителей рода Черкасовых вполне можно изучать историю России. В крайнем случае материалов по истории рода вполне оказалось достаточно, чтобы написать эту работу - историю Черкасовых из Керети, историю Черкасовых (Керетских).

\section{Литература}

ГААО - Государственный архив Архангельской области.

Дикий, 1960-1961 - Дикий А. Неизвращенная история Украины - Руси. В 2 т. Нью-Йорк, 196о1961.

РГАДА - Российский государственный архив древних актов.

ЦАМО РФ - Центральный архив Министерства обороны Российской Федерации.

Черкасов, 2013 - Черкасов А.А. Из истории рода Черкасовых (1685-1954 гг.). Издание 4-е дополненное. Сочи, 2013.

Черкасов, 2013а - Черкасов А.А. Из истории российской северной деревни: Кереть // Русская старина. 2013. № 1(7). C. 15-35.

Cherkasov, 2021 - Cherkasov A.A. Cherkasovs (Keretskys): Feofan Ivanovich Cherkasov (1886-1938)

// European Researcher. Series A. 2021. 12(2): 75-80.

Cherkasov, 2021a - Cherkasov A.A. Cherkasovs (Keretskys): Pavel Ivanovich Cherkasov (1938-2010)

// Gardarika. 2021. 8(1): 23-35.

\section{References}

Cherkasov, 2013 - Cherkasov, A.A. (2013). Iz istorii roda Cherkasovykh (1685-1954 gg.) [From the history of the Cherkasov family (1685-1954)]. Izdanie 4-e dopolnennoe. Sochi. [in Russian]

Cherkasov, 2013a - Cherkasov, A.A. (2013). Iz istorii rossiiskoi severnoi derevni: Keret' [From the history of the Russian northern village: Keret]. Russkaya starina. 1(7): 15-35. [in Russian]

Cherkasov, 2021 - Cherkasov, A.A. (2021). Cherkasovs (Keretskys): Feofan Ivanovich Cherkasov (1886-1938). European Researcher. Series A. 12(2): 75-80.

Cherkasov, 2021a - Cherkasov, A.A. (2021). Cherkasovs (Keretskys): Pavel Ivanovich Cherkasov (1938-2010). Gardarika. 8(1): 23-35.

Dikii, 1960-1961 - Dikii, A. (1960-1961). Neizvrashchennaya istoriya Ukrainy - Rusi [The unperverted history of Ukraine - Rus]. V 2 t. N'yu-Iork. [in Russian]

GAAO - Gosudarstvennyi arkhiv Arkhangel'skoi oblasti [State archive of the Arkhangelsk region].

RGADA - Rossiiskii gosudarstvennyi arkhiv drevnikh aktov [Russian state archive of ancient acts]. 
TsAMO RF - Tsentral'nyi arkhiv ministerstva oborony Rossiiskoi Federatsii [Central archive of the Ministry of Defense of the Russian Federation].

\title{
Черкасовы (Керетские): историко-генеалогическое исследование (на материалах второй половины XVIII - первой половины XX вв.)
}

\author{
Александр Арвелодович Черкасов а , b c, * \\ а Черкас глобальный университет, Вашингтон, США \\ b Волгоградский государственный университет, Волгоград, Российская Федерация \\ c Американская историческая ассоциация, Вашингтон, США
}

Аннотация. В работе рассматривается история рода Черкасовых из Керети. Уделено внимание основателю фамилии, девяти поколениям, а также родовым связям и другим материалам генеалогического характера.

В качестве материалов автором были использованы документы Российского государственного архива древних актов (Москва, Российская Федерация), в котором отложились документы 3-й ревизии 1763 г. по селу Кереть; государственного архива Архангельской области (Архангельск, Российская Федерация), в котором имеются материалы с 4-й по 10-ю ревизии (1782-1858 гг.); Национального архива республики Карелия (Петрозаводск, Российская Федерация), в котором хранятся метрические книги по селу Кереть; Центрального архива Министерства обороны Российской Федерации (Подольск, Российская Федерация), благодаря которым установлена судьба нескольких представителей рода, принявших участие во Второй мировой войне.

В заключении автор отмечает, что родоначальником Черкасовых был некто Прокофий (Прокопий), родившийся примерно в 1685 г. Прокофий, по всей вероятности, относился к черкасам казачей этнической группе на территории современной Украины. Сын Прокофия черкас Исак, прибывший в конце 1720-х гг. в Кереть, был записан как Исак Черкасов и определен в крестьянское сословие. С конца 1720-х гг. и до середины 1950-х гг. (вплоть до закрытия села Кереть в годы советской власти) Черкасовы и село Кереть будут неразрывно связаны. За это время в Керети родилось 7 поколений Черкасовых (нужно напомнить, что первые два поколения были пришлыми Прокофий и его сын Исак). Главным занятием Черкасовых в Керети был рыбный промысел. За годы своей жизни в селе Черкасовы исполняли государственные повинности (набирались в русскую армию в качестве рекрутов, принимали участие в Первой и Второй мировых войнах), платили налоги. Среди Черкасовых были промышленники до революции, инженеры, чиновники, учителя, изобретатели, предприниматели в советский и современный российский периоды. Среди них были жертвы политических репрессий в СССР и советские лауреаты государственной премии...

Ключевые слова: Черкасовы (Керетские), черкас Прокофий, Исак Черкасов, ревизии, село Кереть, Российская империя.

\footnotetext{
${ }^{*}$ Корреспондирующий автор

Адреса электронной почты: a.cherkasov@cherkasgu.net (А.А. Черкасов) 